\title{
Zoufalství z vejšky
}

Psáno k 21. 8. 2018

\section{Jana Dlouhá}

Envigogika 13 (1) - I nspirations/ I nspirace

Published/ Publikováno 21. 8. 2018

DOI: $\underline{10.14712 / 18023061.574}$

\section{Abstrakt}

Reakce na to, co se děje v českém vysokém školství: plagiátorské kauzy ministrů nové české vlády, i "dopis statečného" - zkušenost profesora Tomáše Grima, který se rozhodl systém předstírání vzdělanosti opustit.

\section{Klíčová slova}

Vzdělávací systém; vysoké školství; plagiátorství; etika

\section{Abstract}

Reflection of the current situation in the Czech higher education: plagiarism of the ministers of the new Czech government, and the experience of professor Tomáš Grim, who opted to leave the system of pretentious education.

\section{Key words}

Educational system; higher education; plagiarism; ethics 
České vysoké školství trpí závratí. Jinak si nelze vysvětlit, proč by mělo být vysoké. Pěstuje snad nějaké vysoké ideály? Má vysoké nároky? Snad jen cena za to, že jej někdo vystuduje, je vysoká - i když se nepočítá v penězích. Absolvent platí ztraceným časem, podlomeným charakterem nebo i sebevědomím (což se obvykle vylučuje, ale může $k$ tomu dojít i současně), a všeobecnou ztrátou iluzí. O co v tom systému jde, je titul (před nebo za jménem), který je často k mání za jakoukoli (morální) cenu.

Proč je tato zpráva součástí Novinek? Ne, rozhodně to není nic nového. Do tohoto stavu naše společnost dospěla pomalu, pliživě, drobnými ústupky a vlastní pohodlností. Studenti brzy zjistili, že znalosti nabízené většinou škol jsou celkem k ničemu (pro špatnou strukturu a obsah studijních programů / pro marasmus současného světa, který neví, co je podstatné - nehodící se škrtněte). Učitelé s hrůzou (a někteří s povděkem) zaznamenali, že na jejich učitelských a odborných kvalitách moc nezáleží, takže studenti mohou být jen dobrou záminkou pro př́stup $\mathrm{k}$ institucionálním financím a další kariérní postup. Jedni pro druhé se stali rukojmími, a protože závislost je vzájemná, vyhovuje to většinou oběma stranám. Jedni mají své tituly, a ti druzí vlastně také, a navíc poměrně úctyhodnou obživu. Nikdo nepřemýšlí, jaký to má smysl, kritická sebereflexe je věc neznámá. Jasno by tu mohla udělat věda, o kterou vlastně jde především; ta se ale vzdala jak svého teoretického odstupu, tak bezprostřední užitečnosti ve věci hledání a zajištóvání pokroku. Stala se z ní parodie na vědu, chrlič formálně správných výsledků. Pravým cílem oné hry, jejiž akcie jsou proklatě vysoko, je pak hodnocení těchto výtvorů.

Že pro výše uvedená tvrzení nemáme doklady? Není zde cílem podrobně analyzovat problémy systému, který je tak složitý, že to přesahuje možnosti tohoto krátkého článku. Jenže i vzdálenému pozorovateli je jasné, že (přinejmenším) vysoké školství už přišlo o všechny sebečistící mechanismy. Ilustrují to př́klady z poslední doby. Debaty o plagiátorství našich ústavních činitelů jsou vedeny pouze s ohledem na autory bakalářských nebo diplomových prací, kteří jsou hlavními viníky. Instituce, které takové práce dopustily, se rozhodně nechystají k veřejnému pokání. Na pořadu dne tu není revize zavedených postupů výuky a hodnocení jejích výsledků. To se u nás "nenosí", a v současném systému to ani není potřeba - nic jej neohrožuje. Autonomie - tradiční a nezpochybnitelná výsada vysokých škol - totiž dokáže ochránit nejen vzdělanost proti rozmarům politiky, ale i kryje podvody pod rouškou její ctihodnosti. Funguje to podobně jako poslanecká imunita...

Můžeme nabídnout ještě jiný př́klad z letoška. Jeden ze statečných vysokoškolských profesorů, Tomáš Grim, si řekl Dost! Řekl to nejen sobě, ale všem, které by to mohlo a mělo zajímat - jeho veřejné, a hodně hlasité prohlášení si můžete přečíst zde. Odstoupil z funkce, kterou už nepovažoval za čestnou; vzdal se práce, která jej těšila. Společenství stejně smýšlejících akademických pracovníků opatrně zareagovalo - na Facebooku a podobně. Díky tomu máme několik zajímavých a poučných zkušeností (zde). A co na to škola, o kterou se jedná? Na pomoc si přivolala etickou komisi, která na "stěžovateli" vynutila omluvu. Hlavně pro porušení formálních pravidel vyjadřování - ne "oprávněnosti (tj. obsahu) kritiky" (více zde).

A tak to začíná vypadat, že máme vážný problém. Nezávislost vysokých škol - to je zahleděnost do sebe sama. Panuje zde hierarchie, která kritiku nepřipouští. A nezdravé principy se rychle širí: podvod jako metoda kariérního postupu, princip "vládnutí“ i podmínka výběru dalších spolupracovníků. Vzniká prostředí bez skutečných nároků, jemuž se přizpůsobuje i např́iklad nastavení oborového zaměření a požadavky na studenty. Skutečná kvalita už ani není žádoucí - ohrožuje systém založen na pohodlnosti. $V$ malých oborech a nepř́liš úspěšných to jde takříkajíc samo, a je pouze otázkou času, kdy se nemoc rozšírí všeobecně, napadne také obory větší nebo životaschopnější. 
Jenomže jestli se nepokusíme tyto vnitřní procesy ovlivnit, přestanou být skutečné; bude to jen předstírání skutečnosti. Hra na něco, co by mělo být, ale není. Dodržování pravidel, jen abychom vyhráli - obehráli ostatní. Už ted' nás obklopuje svět jako - a my si pěstujeme na něm závislost. To, že $v$ něm jsme, si jenom myslíme - pravda je taková, že on je $v$ nás, a docela hezky nás už rozežral. Pronikl hluboko i do institucí, které měly na starost „posvátné" atributy naší společnosti - např́iklad vzdělanost.

Nic nového, už dlouho a pomalu si zvykáme. Ted' je ale čas, kdy bychom se o to měli začít opravdově zajímat. Bez instituce, které bychom mohli plně důvěřovat, která by nás vybavila spolehlivými, (vědecky i lidsky) prověřenými argumenty, snadno rezignujeme na základní hodnoty. Pravdu, spravedlnost, čest,... Pojmy, které se dokonce těžko vyslovují, protože každý $z$ nich nese $v$ sobě nejen historii probouzení a bolestného prosazování ideálů, ale také, později, jejich zneužití. A my si nedáváme práci s jejich očištováním. Nepečujeme o tyto pojmy a názory - tak, aby byly nejen fakticky podložené, ale také spojené s morální autoritou toho, kdo s nimi nakládá. Zanedbáváme tak sami sebe, a to vědomě, se souhlasem všech; a tím se vydáváme do moci manipulátorů všeho druhu - kteří si s námi už pomalu dělají, co chtějí. Jako by na tom záleželo, že. I to už přece z nedávné minulosti známe... Snad v téhle hře jde právě o tohle - aby se historie zopakovala. I když ted' už mírnějšími prostředky. 